\title{
IAMJ
}

INTERNATIONAL

AYURVEDIC

MEDICAL JOURNAL

\section{A COMPARATIVE CLINICAL STUDY TO EVALUATE THE EFFICACY OF LAVANGADI GUTIKA AND PIPPALYADI GUTIKA IN KAPHAJA KASA}

\author{
$\underline{\text { Risin Sugunan }}^{1}, \underline{\text { Zenica D'souza }}^{2}$ \\ 13rd year PG scholar, Dept. of Kayachikitsa, Alva's Ayurveda Medical College \& Hospital, Moodbidri, \\ Karnataka, India \\ ${ }^{2}$ Professor\& HOD, Yenepoya Ayurveda Medical College \& Hospital, Naringana, Mangaluru, Karnataka, India
}

Corresponding Author: drrisin1299@gmail.com

https://doi.org/10.46607/iamj0909102021

(Published Online: October 2021)

Open Access

(C) International Ayurvedic Medical Journal, India 2021

Article Received: 28/09//2021 - Peer Reviewed: 07/10/2021 - Accepted for Publication: 08/10/2021

\section{Check for updates}

\begin{abstract}
Kasa is one of the Pranavaha Srothodusti vikara which hinders normal life. Kaphaja Kasa is a type of Kasa with Vata and Kapha as predominant doshas and present with Prabhuta, Ghana and Bahala kapha. Kaphaja Kasa can be best compared with Chronic Bronchitis. If left untreated it leads to various conditions like Swasa, Kshaya, Chardi, Svarasaadha etc. This signifies the importance of its early management. The present study was conducted on 40 diagnosed subjects of Kaphaja Kasa who were randomly allocated into 2 groups with 20 patients each. $L a-$ vangadi gutika was taken in Group A and Pippalyadi gutika in Group B. Medicines was given for 30 days and the data was collected from the subject at baseline, $16^{\text {th }}$ day, $31^{\text {st }}$ day and on $46^{\text {th }}$ day (follow up). The result of the study showed that there was a statistically significant difference in the assessment parameters in both the groups from baseline. However no statistically significant difference was observed between the effect of Lavangadi guti$k a$ and Pippalyadi gutika in the management of Kaphaja Kasa suggesting that both interventions were having a significant effect on the condition.
\end{abstract}

Keywords: Kaphaja Kasa, Lavangadi gutika, Pippalyadi gutika 


\section{INTRODUCTION}

Respiratory disorders have become more prevalent these days due to air pollution, occupational hazards etc. Decreased immunity and non-adaptability against environmental influences lead to various respiratory problems. In recent years, there has been an extraordinary increase in incidence related to the respiratory system. Cough is the fifth most common symptom for which patients seek medical care ${ }^{1}$.

Kasa is one of the most common ailments affecting the Pranavaha srotas and Kaphaja Kasa is one among them. Vata and Kapha are the two key dosha involved in the pathogenesis of Kaphaja Kasa. Kaphaja Kasa presents with cough along with copious thick, slimy sputum. ${ }^{2}$. If Kasa is left untreated, it leads to diseases like Swasa, Kshaya, Chardi, Svarasaadha etc. Hence it should be treated at the earliest $^{3}$.

Cardinal symptoms of Kaphaja Kasa are similar to chronic bronchitis. According to estimates from national interviews taken by the National Center for Health Statistics, approximately 9.5 million people or $4 \%$ of the population were diagnosed with Chronic Bronchitis ${ }^{4}$.

Long term use of corticosteroids and bronchodilators causes various adverse side effects like the weakened immune system, loss of bone mineral density, loss of appetite, dryness of mouth, throat irritations etc. So, there is a serious and urgent need for safer management without adverse side effects.

Many herbal formulations are described in Ayurveda and must be explored for their therapeutic effect in Kasa. Hence in the present study, Pippalyadi gutika ${ }^{5}$ mentioned in Yogaratnakara kasa chikitsa was evaluated for its therapeutic efficacy and compared with the effect of Lavangadi gutika ${ }^{6}$ mentioned in Vaidhyajivanam, swasa kasa chikitsa for the therapeutic action in Kaphaja Kasa.

\section{OBJECTIVES OF STUDY:}

1. To evaluate the therapeutic effect of Lavangadi gutika in the treatment of Kaphaja Kasa

2. To evaluate the therapeutic effect of Pippalyadi gutika in the treatment of Kaphaja Kasa

3. To compare the therapeutic effect of Lavangadi Gutika and Pippalyadi Gutika in the treatment of Kaphaja Kasa

\section{MATERIALS AND METHODS:} SOURCE OF DATA:

Raw drugs required were identified and collected from the source of availability and the medicines were prepared according to the literature references at Rasashastra and Baishajya Kalpana Laboratory, Alva's Ayurveda Medical College, Moodbidri.

\section{CLINICAL SOURCE:}

- Patients diagnosed as Kaphaja Kasa were randomly selected from the Kayachikitsa Outpatient Department and In-Patient Department of Alva's Ayurveda Medical College and Hospital, Moodbidri.

- Medical camps and other referrals.

\section{METHODS OF COLLECTION OF DATA}

a) SAMPLE SIZE:

Minimum of 40 patients, irrespective of gender, religion, occupation, marital status, educational status, socioeconomic status, fulfilling the diagnostic criteria, inclusion criteria were selected for the study. They are randomly divided into two equal groups, groups A and B of 20 patients each.

STUDY DESIGN: Parallel group comparative clinical study

BLINDING: Single-blind

METHOD OF SAMPLING: Lottery Method b) PLAN OF STUDY 
Table 1: Shows interventions

\begin{tabular}{|l|l|}
\hline GROUP A & GROUP B \\
\hline Lavangadi gutika & Pippalyadi gutika \\
\hline Matra - 500mg twice daily after food & Matra $-500 \mathrm{mg}$ twice daily after food \\
\hline Anupana - Warm water & Anupana - Warm water \\
\hline Duration - 30days medication + 15days follow up & Duration - 30days medication + 15days follow up \\
\hline
\end{tabular}

\section{OBSERVATIONAL PERIOD:}

- Assessments during the trial period: On the $0^{\text {th }}$, $16^{\text {th }}$ and $31^{\text {st }}$ day of the study period.

- Follow up assessment was done after 15 days i.e on the $46^{\text {th }}$ day of the study period.

- Total study duration including Follow up: 45days.

\section{DIAGNOSTIC CRITERIA:}

Kasa (cough) with Sandra and Bahula Kapha Nishteevana (Spitting of thick phlegm in large quantity) with or without following symptoms.

- Aasyamadhurya (Sweetness in the mouth)

- Aruchi (Anorexia)

- Shirashula (Headache)

- Peenasa (Chronic rhinitis)

- Utklesha (Nausea)

\section{INCLUSION CRITERIA:}

- Patients fulfilling signs and symptoms of Kaphaja Kasa.

- Patients having age above 16 years \& below 60 years.

\section{EXCLUSION CRITERIA:}

- Patients with the complication of Kasa like Tuberculosis, Emphysema, Pneumonia etc.

- Patients with systemic or metabolic disorders that would interfere with the present study.

- Pregnant women and lactating mothers.

- Patients on Steroids in any form.

ASSESSMENT CRITERIA:

\section{SUBJECTIVE PARAMETER}

- Kasa (cough)

- Sandra and Bahula Kapha Nishteevana (Spitting of thick phlegm in large quantity)

- Aasyamadhurya (Sweetness in the mouth)

- Aruchi (Anorexia)

- Shirashula (Headache)

- Peenasa (Chronic rhinitis)

- Utklesha (Nausea)

\section{OBJECTIVE PARAMETER}

- Blood investigation - Hb, TC, DC, ESR, AEC

- Chest X-Ray to rule out other conditions.

- Any relevant Investigation if required.

OBSERVATIONS AND RESULTS:

Table 2: Showing Demographic data

\begin{tabular}{|l|l|l|}
\hline CHARACTERS & PREDOMINANCE & PERCENTAGE \\
\hline Age & $26-35$ & $32.5 \%$ \\
\hline Gender & Male & $52.5 \%$ \\
\hline Religion & Hindu & $62.5 \%$ \\
\hline Marital status & Married & $62.5 \%$ \\
\hline Occupation & Students & $30 \%$ \\
\hline Socioeconomic status & Middle class & $77.5 \%$ \\
\hline Habitat & Urban & $90 \%$ \\
\hline Dietary habit & Mixed & $77.5 \%$ \\
\hline Prakriti & Kapha-vata & $62.5 \%$ \\
\hline Satmya & Madhyama & $90 \%$ \\
\hline Satwa & Madhyama & $65 \%$ \\
\hline Abhyavaharana shakti & Avara & $57.5 \%$ \\
\hline Jarana shakti & Avara & $60 \%$ \\
\hline
\end{tabular}


STATISTICAL TEST: The groups were compared from baseline to assessment time points and the statistical significance of improvement obtained was analyzed with Wilcoxon Signed Rank Test and
Mcnamer test. Comparison of the result between the groups was done using Mann-Whitney U Rank Sum Test.

Table 3: Effect on Group A and Group B in Primary complaints

\begin{tabular}{|c|c|c|c|c|c|c|c|c|}
\hline CRITERIA & $\begin{array}{l}\text { MEAN } \\
\text { BT }\end{array}$ & $\begin{array}{l}\text { MEAN AT2 } \\
\left(31^{\text {st }} \text { day }\right)\end{array}$ & M.D & $\%$ & S. D & S. E & $\begin{array}{l}\text { WSRT } \\
\text { VALUE }\end{array}$ & p VALUE \\
\hline & \multicolumn{8}{|c|}{ GROUP A } \\
\hline $\boldsymbol{K A S A}$ & 2.00 & 0.45 & 1.55 & 77.50 & 0.510 & 0.117 & 210 & $<0.001$ \\
\hline \multirow[t]{2}{*}{$\begin{array}{l}\text { KAPHA } \\
\text { NISHTEEVAN }\end{array}$} & 2.45 & 0.90 & 1.55 & 63.27 & 0.510 & 0.117 & 210 & $<0.001$ \\
\hline & \multicolumn{8}{|c|}{ GROUP B } \\
\hline $\boldsymbol{K A S A}$ & 2.10 & 0.40 & 1.70 & 80.95 & 0.470 & 0.108 & 210 & $<0.001$ \\
\hline $\begin{array}{l}\text { KAPHA } \\
\text { NISHTEEVAN }\end{array}$ & 2.55 & 0.80 & 1.75 & 68.63 & 0.444 & 0.102 & 210 & $<0.001$ \\
\hline
\end{tabular}

ASSOCIATED COMPLAINTS:

Table 4: Effect in Group A and Group B on Aruchi

\begin{tabular}{|c|c|c|c|c|}
\hline & $\mathbf{N}$ & MEAN & STD. DEVIATION & EXACT SIG. (2-TAILED) \\
\hline & \multicolumn{4}{|c|}{ GROUP A } \\
\hline BT & 20 & .50 & .513 & \multirow[b]{2}{*}{ BT \& AT2 - 0.002} \\
\hline AT2 & 20 & .00 & .000 & \\
\hline & \multicolumn{4}{|c|}{ GROUP B } \\
\hline BT & 20 & .70 & .470 & \multirow[b]{2}{*}{ BT \& AT2 - .000 } \\
\hline AT2 & 20 & .00 & .000 & \\
\hline
\end{tabular}

Assessment of certainly associated complaints by Mean and Percentage: Statistical analysis was not done for associated complaints Shirashoola, Peenasa and Utklesha as these symptoms were present only in a few patients. Hence the improvement was assessed by Mean and Percentage of the score obtained.

Table 5: Effect on Group A and Group B in other Associated Symptoms

\begin{tabular}{|l|l|l|l|l|}
\hline \multicolumn{4}{|l|}{ Group A } & Group B \\
\hline Symptoms & No. Of patients & Percentage of relief & No. Of patients & Percentage of relief \\
\hline Shirashoola & 6 & $16.67 \%$ & 5 & $100 \%$ \\
\hline Peenasa & 7 & $100 \%$ & 9 & $100 \%$ \\
\hline Utklesha & 2 & $100 \%$ & 1 & $0 \%$ \\
\hline
\end{tabular}

Table 6: Comparison of effects in Group A and Group B

\begin{tabular}{|l|l|l|l|l|l|l|}
\hline \multirow{2}{*}{ Criteria } & \multicolumn{4}{l|l}{ Mean Difference } & Mann- Whitney Rank Sum Test & \multirow{2}{*}{ Remark } \\
\cline { 2 - 7 } & Group A & Group B & U Value & Z Score & P-Value & \\
\hline Kasa & 1.55 & 1.7 & 170 & 0.798 & 0.424 & Ns \\
\hline Kapha Nishteevana & 1.55 & 1.75 & 160 & 1.068 & 0.285 & Ns \\
\hline Aruchi & 0.5 & 0.7 & 160 & 1.068 & 0.285 & Ns \\
\hline Shirashoola & 0.28 & 0.08 & 176 & 0.649 & 0.516 & Ns \\
\hline Peenasa & 0.20 & 0.21 & 190 & 0.256 & 0.795 & Ns \\
\hline Utklesha & 0.03 & 0.10 & 198 & 0.040 & 0.968 & Ns \\
\hline
\end{tabular}


Table 7: Overall effect of Group A and Group B in Percentage and numbers Effect Of Treatment in Group a and B

\begin{tabular}{|l|l|l|l|}
\hline CLASS & Grading & No Of Patients in Group A & No Of Patients in Group B \\
\hline $0 \%$ & No improvement & 0 & 0 \\
\hline $1-25 \%$ & Mild improvement & 0 & 0 \\
\hline $26-50 \%$ & Moderate improvement & 6 & 4 \\
\hline $51-75 \%$ & Marked improvement & 10 & 7 \\
\hline $76-99 \%$ & Significant improvement & 2 & 4 \\
\hline $100 \%$ & Complete Relief & 2 & 5 \\
\hline
\end{tabular}

\section{DISCUSSION}

In the present study, the effect of Lavangadi gutika and Pippalyadi gutika on Primary outcomes Kasa vega and Kapha Nishteevana in Group A and Group $B$ respectively were statistically significant from baseline values While comparing both the Groups statistically insignificant result at $p>0.05$ was found, indicating both treatments were effective. 10 patients in Group A and 14 patients in Group B had Aruchi. The percentage of relief was $100 \%$ in both Groups. While comparing both the Groups statistically insignificant result at $\mathrm{p}>0.05$ was found. Other associated symptoms like Shirashoola, Peenasa and Utklesha were present only in some study volunteers at baseline and showed improvement on receiving treatments in both the groups.

\section{Probable mode of action of Lavangadi gutika}

Lavangadi gutika contains Katu, Tikta, Kashaya rasa pradhana, Katu vipaka and Ushna veerya drugs. So, these drugs help in Kaphavata shamana. Lavanga, Maricha, Vibitaki tvak has deepana and paachana property. Since Kaphaja Kasa is an agnimandhya janya, Aamashayottha vikara these drugs act on Amashaya, help in the digestion of Ama and improve Agni. Lavanaga because of its Katu rasa and Tikshna guna have Kapha vilayana property. Vibhitaki has Bhedana property that helps in the removal of Kapha. Vibitaki has bronchodilator action. Hence it relieves cough $^{7}$. All the drugs in the Lavangadi gutika have Kasagna property. Maricha because of its Katu rasa, Teekshna guna, Usna veerya has Kaphavata shamana property. Due to its bronchodilator property Maricha is beneficial in cough and respiratory disorders $^{8}$.Khadira sara has anti-inflammatory property ${ }^{9}$. Hence the drugs in combination help in the reduction of Kaphaja kasa. These properties in the formulation's drugs have proved to be effective in the condition of Kasa.

\section{Probable mode of action of Pippalyadi gutika}

Pippalyadi gutika contains Katu, Tikta Kashaya rasa pradhana, Ruksa, Tikshna, Ushna veerya, Katu vipa$k a$ dravyas. Because of that, it has Kaphavatahara property. Drugs like Pippali, Sunthi etc have deepana and Paachana properties. So, it removes ama and kindles agni. Pippali and Sunthi because of their Anti-inflammatory action inhibit inflammatory mediators i.e, leukotriene, interlukins, prostaglandin released by macrophages, T lymphocytes and Neutrophils. Hence, they reduce excess mucous secretion in the respiratory tract ${ }^{10,11}$. A drug like Pippali has rasayana properties, so it increases Agni and Bala and nourishes Rasa dhatu. Drug like Haritaki has Apana anulomana property which is initiating property for samprapti of Kaphaja Kasa. Sati because of its Chedana property removes obstruction of Vata by Kapha in Pranavaha srotus. Mucolytic and mucokinetic action of Sati depolymerises the mucopolysaccharides and liberates lysosomal enzymes which break the tenacious mucus plugs present in the respiratory tract and causes expectoration of Sputum ${ }^{12}$. Pushkara moola possesses Hridya property, and it acts on Hridaya which is the mula sthana of Pranavaha and Rasavaha srotas. A drug like Mulaka has Tridosahara property. Because of the above properties Pippalyadi gutika help in the reduction of Kaphaja Kasa and associated symptoms.

\section{CONCLUSION}

Both Lavangadi gutika and Pippalyadi gutika showed a statistically highly significant effect on primary 
outcomes Kasa and Kapha nishteevana. Associated symptom Aruchi showed a statistically highly significant effect in Group B and significant effect in Group A. Peenasa, Shirashoola showed $100 \%$ improvement in both Groups and Utklesha showed 100\% improvement in Group A and No improvement in Group B. While comparing the effect in both the groups, there was no statistically significant difference between groups after treatment. As a result, $\mathrm{H}_{0}$ is accepted and has been proven that there is no significant difference in the effect of Lavangadi gutika and Pippalyadi gutika in the symptomatic management of Kaphaja Kasa. Both formulations in this study had Kaphavata hara, Deepana, Pachana, Kapha vilayana, Srotoshodhana and antiinflammatory properties which are needed to break down the samprapti of Kaphaja Kasa.

\section{REFERENCES}

1. Deeja CR, Satya Priya T, Venkat Shivudu K, Ram Reddy GP. Clinical evaluation of hareetakyadi Gutika on Kaphaja Kasa. International Journal of Ayurvedic Medicine 2013; 4(4):394.

2. Acharya Agnivesha. Charaka Samhita, Ayurveda Deepika Commentary of Chakrapani datta, edited by Vaidya Jadavaji Trikamji Acharya, Published by Chaukhamba Surbharati Prakashan, Edition: Reprint 2008, Chikitsa Sthana Chapter 18th/ 17-19, Pg no540.

3. Vagbhata. Astanga Hridaya with Commentaries Sarvanga Sundari of Arunadatta and Ayurveda Rasayana of Hemadri, collected by Dr Anna Moreshwar Kunte and Edited by Pt. Harisadashiv Shastri Paradkar vaidya, Varanasi: Choukamba Surbharthi Prakashana, Reprint: 2010, Nidana Sthana Chapter 3rd / 25-26, Pg no- 470.

4. Shilpa L.S., Prashanth A.S. A Critical Review on the Etiopathogenesis and Treatment of Kaphaja Kasa (Chronic Bronchitis). Journal of Ayurveda and Integrated Medical Sciences 2016; 1(4):118.

5. Yoga Ratnakara, Sanskrit Text with English Translation and Edited by Dr Madham Shetty Suresh Babu, Published by Chaukhambha Publication, Edition First 2005, Kasa Chikitsa Pg no- 497.

6. Lolimbaraja.Vaidyajivanam, with Dipika Commentary by Rudrabhatta and Edited by Priya Vrat Sharma,
Published by Chaukhamba Surbharati Prakashan, Edition 2005, Chapter 3/7, Pg no-51.

7. Trivedi, V.P., S. Nesamany and V.K. Sharma, 1979. A clinical study of the anti-tussive and anti-asthmatic effects of Vibhitakphal Churna (Terminalia bellerica Roxb.) in the cases of Kasa-Swasa. J. Res. Ayurveda Siddha, 3: 1-8.

8. Majeed M, Badmeev V and Rajendran R: Use of piperine as a bioavailability enhancer. United States $\mathrm{Pa}$ tent. 1999; (5): 972, 382.

9. Burnett BP, Silva S, Mesches MH, Wilson S, Jia Q. Safety evaluation of a combination, defined extract of Scutellaria baicalensis and Acacia catechu. J Food Biochem 2007; 31:797e825.

10. Sarvesh Kumar, pragya arya, Chandrani, Mukherji, Novel aromatic ester from Piper longum and its analogues inhibit expression of Cell Adhesion molecules on Endothelial cells, The council of Scientific and Industrial Research (CSIR) New Delhi, Published on 11/09/2005.

11. Kiuchi F, Iwakami S, Shibuya M, Hanaka F, Sankawa U.: Inhibition of prostaglandin and leukotrine biosynthesis by gingerols and diarylheptanoid. Chem. Pharm Bull. 40: 387-91(1992).

12. Pharmacologyonline 2:633-642(2011)_ewsletter Sravani and Paarakh Hedychium spicatum Buch.Ham. - An Overview.

\section{Source of Support: Nil Conflict of Interest: None Declared}

How to cite this URL: Risin Sugunan \& Zenica D'souza: A Comparative Clinical Study To Evaluate The Efficacy Of LaVangadi Gutika And Pippalyadi Gutika In Kaphaja Kasa. International Ayurvedic Medical Journal \{online\} 2021 \{cited October 2021\} Available from: http://www.iamj.in/posts/images/upload/2347_2352.pdf 